\title{
Evaluation of the Satisfaction of Undergraduate Radiological Sciences Students Toward their Clinical Training Experience
}

\author{
TAMADER AL-RAMMAH, Ph.D. \\ The Department of Radiological Science, King Saud University, Riyadh, Saudi Arabia
}

\begin{abstract}
Background: Radiology plays a very important role in health care system. Nowadays, most of the diagnoses are based on it.

Aim of Study: To evaluate radiological sciences students' satisfaction toward their clinical training experience and to compare their levels of satisfaction experienced at a university hospital and a Ministry of Health (MOH) Hospital.

Material and Methods: A total of 92 radiology students from four levels in addition to internship were included in this study. A data collection sheet was constructed by the researcher to assess students' satisfaction toward their clinical training experience. The survey was designed to evaluate students' satisfaction during clinical experience in general and to compare the level of satisfaction of students in two hospitals, one was university affiliated and the other was $\mathrm{MOH}$ affiliated.

Results: Students' mean satisfaction scores were within the "satisfied" range. However, participant students were mainly dissatisfied with their training at the MOH hospital. The item with least satisfaction was related to the hospital staff being friendly and approachable $(40.2 \%)$, while the item with highest satisfaction was related to adequacy and accessibility of learning resources at hospital (64.1\%). Students enjoyed their training significantly more at university hospital $(p=0.008)$; the staff were significantly less friendly at the MOH hospital ( $p=0.018)$; internship was significantly more preferred at the university hospital $(p<0.001)$; and students felt as part of the team during their placement significantly less at the MOH hospital $(p<0.001)$.
\end{abstract}

Conclusions: Radiological sciences students are mainly satisfied with their clinical training. They enjoyed training at the university hospital more than at a MOH hospital. Students' feedback should be regularly taken to ensure that they receive the best placement and training environment. Educational and training institutions, supervisors and clinical trainers must collaborate to develop and implement strategies in order to improve practice.

Key Words: Radiological science - Clinical training - Satisfaction-Hospital placement.

Correspondence to: Dr. Tamader Al-Rammah, The Department of Radiological Science, King Saud University, Riyadh, Saudi Arabia

\section{Introduction}

RADIOLOGICAL technology is an important component of the health care system. Qualified radiologic students must acquire enough clinical skills and theoretical knowledge during their training to succeed, and also to promote their organizations as well as the health care system [1] .

Clinical education is considered one of the learning opportunities that offer students face-toface interactions with patients and peers. It also facilitates professional socialization and provides students with different leaning experience other than the college-based learning [1,2] .

Clinical studies have been described as an experiential learning. It is an active learning by doing. There are three distinct stages of experiential learning. In the early stage, students concentrate on learning technical skills. As they perfect their technical skills, the emphasis turns to the second stage, i.e., learning how to function as a professional, by observing how other professionals perform in their roles and by developing values and attitudes associated with the professional role. In the last stage, students begin to set their own learning agendas and choose their own learning experiences. By the end of their clinical learning experience, students have become more independent and more self-directed in what and how they need to learn [3].

Students' satisfaction is a major component of the current educational approaches to ensure the best training experience. Constantly measuring and evaluating students' satisfaction levels toward their learning experience can be a great guide to educators to improve and develop better teaching strategies, such as classroom teaching or clinical placements [4]. 
This study aimed to evaluate radiological sciences students' satisfaction toward their clinical placement experience and to compare their levels of satisfaction experienced at a university and a Ministry of Health Hospital.

\section{Patients and Methods}

The study population comprised students of the Bachelor of Radiological Sciences Program at King Saud University, Riyadh City, Saudi Arabia. These students undertake one preparatory year followed by 3 years of theoretical, practical and clinical training. Clinical training is a major component of the program; during which clinical courses are distributed over 2 years (four semesters) to prepare students before enrolling into the internship year. Then, students have to spend a one-year internship before they graduate.

This study included all students at their four semesters of clinical training in addition to those at internship $(n=92)$ during the academic year 2015-2016.

A data collection sheet was designed by the researcher to assess students' satisfaction toward their clinical training experience. It comprised 26 multiple-choice questions divided into two parts. The first part comprised 15 questions to measure students' satisfaction during their clinical placement in general, while the second part comprised 11 questions that directly assess students' level of satisfaction according to their training hospital.

For scoring of responses, a 5-point Likert scale was adopted for each question, (i.e., $1=$ not at all, $2=$ to a littler extent, $3=$ to some extent, $4=$ to a large extent, $5=$ to a very large extent). Students' average scores were graded into either "satisfied" or "dissatisfied". Students whose average score was three or more were categorized as "satisfied" while students having average score less than three were considered as "dissatisfied".

An electronic version of the study questionnaire was uploaded to the university website and each student was invited to answer the questions after signing an electronic informed consent form. Participation was anonymous and voluntary. The Institutional Research Board (IRB) approval was obtained before starting data collection.

Collected data were analyzed using the Statistical Package for Social Sciences, Version 23, (SPSS Inc, Chicago IL, USA). Descriptive statistics (i.e., mean, standard deviation, frequency and percentage) were applied. Students' satisfaction levels during the clinical training in two different hospitals (i.e., university-affiliated or Ministry of Health-affiliated) were calculated the and Chisquare test $\left(\chi^{2}\right)$ was applied to check the significance of differences between satisfaction levels in different training hospitals.

\section{Results}

As shown in (Table 1), most of the values were in the "satisfied" range, with scores between 3 and 4. However, students' least satisfaction was related to "my performance was observed throughout the placement and there was daily evaluation" with a mean \pm SD of $2.82 \pm 1.36$, while their highest satisfaction was related to "it is important to go to different hospitals for training to have different clinical experiences" with a mean \pm SD of $4.54 \pm$ 0.73 .

Table (1): Students' satisfaction scores (mean and SD) about clinical posting.

\begin{tabular}{|c|c|c|c|}
\hline No. & Statements & Mean & SD \\
\hline 1 & I enjoyed all the clinical placement during my study & 3.59 & 0.89 \\
\hline 2 & The staff were friendly and approachable & 3.51 & 0.97 \\
\hline 3 & I always felt part of the team & 3.25 & 1.17 \\
\hline 4 & I found respect from the clinical supervisor and staff & 3.58 & 0.99 \\
\hline 5 & I was able to achieve the learning outcome/standard of proficiency during the clinical placement & 3.87 & 0.76 \\
\hline 6 & My performance was observed throughout the placement and there was daily evaluation & 2.82 & 1.36 \\
\hline 7 & My training schedule covered all the imaging modalities & 3.72 & 1.03 \\
\hline 8 & I was able to improve my clinical skills & 3.47 & 0.98 \\
\hline 9 & I was able to improve my communication skills with the patients & 3.42 & 1.29 \\
\hline 10 & I was able to improve my communication skills with the staff & 3.38 & 1.11 \\
\hline 11 & Clinical practice and program curriculum were well structured together and integrated each other & 3.77 & 1.04 \\
\hline 12 & I am satisfied with my clinical practice during my study & 3.42 & 1.02 \\
\hline 13 & I was able to see variety of cases and procedures during my training & 3.45 & 1.12 \\
\hline 14 & It is important to go to different hospitals for training to have different clinical experiences & 4.54 & 0.73 \\
\hline 15 & I am able to plan and implement patient care after my clinical training & 3.07 & 1.15 \\
\hline
\end{tabular}


Table (2): Students' satisfaction regarding different items according to their training hospital.

\begin{tabular}{|c|c|c|c|c|c|c|}
\hline Items & & $\mathrm{MOH}$ & University & Both & Total & $p$-value \\
\hline - I enjoyed my training during my placement at .. & $\begin{array}{l}S \\
D\end{array}$ & $\begin{array}{l}13(33.3 \%) \\
26(66.7 \%)\end{array}$ & $\begin{array}{ll}9 & (52.9 \%) \\
8 & (47.1 \%)\end{array}$ & $\begin{array}{l}25(69.4 \%) \\
11(30.6 \%)\end{array}$ & $\begin{array}{l}47(51.1 \%) \\
45(48.9 \%)\end{array}$ & 0.008 \\
\hline - The staff were friendly and approachable & $\begin{array}{l}S \\
\mathrm{D}\end{array}$ & $\begin{array}{l}13(27.7 \%) \\
34(72.3 \%)\end{array}$ & $\begin{array}{l}9(42.9 \%) \\
12(57.1 \%)\end{array}$ & $\begin{array}{ll}15 & (62.5 \%) \\
9 & (37.5 \%)\end{array}$ & $\begin{array}{l}37(40.2 \%) \\
55(59.8 \%)\end{array}$ & 0.018 \\
\hline $\begin{array}{l}\text { - I enjoyed my placement therefore I prefer to take my } \\
\text { internship in .... }\end{array}$ & $\begin{array}{l}S \\
\mathrm{D}\end{array}$ & $\begin{array}{l}15(35.7 \%) \\
27(64.3 \%)\end{array}$ & $\begin{array}{ll}8 & (80 \%) \\
2 & (20 \%)\end{array}$ & $\begin{array}{ll}35 & (87.5 \%) \\
5 & (12.5 \%)\end{array}$ & $\begin{array}{l}58(63.0 \%) \\
34(37.0 \%)\end{array}$ & $<0.001$ \\
\hline - I felt part of the team during my placement in .. & $\begin{array}{l}S \\
\mathrm{D}\end{array}$ & $\begin{array}{l}11(30.6 \%) \\
25(69.4 \%)\end{array}$ & $\begin{array}{l}10(43.5 \%) \\
13(65.5 \%)\end{array}$ & $\begin{array}{l}25(75.8 \%) \\
8(24.2 \%)\end{array}$ & $\begin{array}{l}46(50.0 \%) \\
46(50.0 \%)\end{array}$ & $<0.001$ \\
\hline - I found respect from the clinical supervisor and staff & $\begin{array}{l}S \\
\mathrm{D}\end{array}$ & $\begin{array}{l}16(37.2 \%) \\
27(62.8 \%)\end{array}$ & $\begin{array}{ll}11 & (57.9 \%) \\
8 & (42.1 \%)\end{array}$ & $\begin{array}{l}15(50 \%) \\
15(50 \%)\end{array}$ & $\begin{array}{l}42(45.7 \%) \\
50(54.3 \%)\end{array}$ & 0.272 \\
\hline $\begin{array}{l}\text { - I was able to achieve the learning standards of proficiency } \\
\text { during my practice }\end{array}$ & $\begin{array}{l}S \\
\mathrm{D}\end{array}$ & $\begin{array}{l}17(45.9 \%) \\
20(54.1 \%)\end{array}$ & $\begin{array}{l}11(37.9 \%) \\
18(62.1 \%)\end{array}$ & $\begin{array}{l}11(42.3 \%) \\
15(57.7 \%)\end{array}$ & $\begin{array}{l}39(42.4 \%) \\
53(57.6 \%)\end{array}$ & 0.808 \\
\hline - I was able to improve my clinical skills & $\begin{array}{l}S \\
\mathrm{D}\end{array}$ & $\begin{array}{l}14(42.4 \%) \\
19(57.6 \%)\end{array}$ & $\begin{array}{ll}10 & (55.6 \%) \\
8 & (44.4 \%)\end{array}$ & $\begin{array}{l}15(36.6 \%) \\
26(63.4 \%)\end{array}$ & $\begin{array}{l}39(42.4 \%) \\
53(57.6 \%)\end{array}$ & 0.399 \\
\hline $\begin{array}{l}\text { - I was able to improve my communication skills with the } \\
\text { patients }\end{array}$ & $\begin{array}{l}S \\
\mathrm{D}\end{array}$ & $\begin{array}{l}10(40 \%) \\
15(60 \%)\end{array}$ & $\begin{array}{l}10(45.5 \%) \\
12(54.5 \%)\end{array}$ & $\begin{array}{l}25(55.6 \%) \\
20(44.4 \%)\end{array}$ & $\begin{array}{l}45(48.9 \%) \\
47(51.1 \%)\end{array}$ & 0.429 \\
\hline $\begin{array}{l}\text { - I was able to improve my communication skills with the } \\
\text { staff }\end{array}$ & $\begin{array}{l}S \\
\mathrm{D}\end{array}$ & $\begin{array}{l}13(44.8 \%) \\
16(55.2 \%)\end{array}$ & $\begin{array}{ll}5 & (27.8 \%) \\
13 & (72.2 \%)\end{array}$ & $\begin{array}{l}22(48.9 \%) \\
23(51.1 \%)\end{array}$ & $\begin{array}{l}40(43.5 \%) \\
52(56.5 \%)\end{array}$ & 0.308 \\
\hline $\begin{array}{l}\text { - I did not take on any responsibilities above my level of } \\
\text { competence without supervision }\end{array}$ & $\begin{array}{l}S \\
\mathrm{D}\end{array}$ & $\begin{array}{l}10(52.6 \%) \\
9 \quad(47.4 \%)\end{array}$ & $\begin{array}{ll}4 & (44.4 \%) \\
5 & (55.6 \%)\end{array}$ & $\begin{array}{l}37(57.8 \%) \\
27(42.2 \%)\end{array}$ & $\begin{array}{l}51(55.4 \%) \\
41(44.6 \%)\end{array}$ & 0.724 \\
\hline $\begin{array}{l}\text { - There were adequate and accessible learning resources } \\
\text { within the hospital which enhanced learning }\end{array}$ & $\begin{array}{l}S \\
D\end{array}$ & $\begin{array}{ll}9 & (50 \%) \\
9 & (50 \%)\end{array}$ & $\begin{array}{ll}2 & (100 \%) \\
0 & (0 \%)\end{array}$ & $\begin{array}{l}48(66.7 \%) \\
24(33.3 \%)\end{array}$ & $\begin{array}{l}59(64.1 \%) \\
33(35.9 \%)\end{array}$ & 0.238 \\
\hline
\end{tabular}

MOH: Ministry of Health.

S: Satisfied.

D: Dissatisfied.

Table (2) shows that, regarding almost all satisfaction items, participant students were dissatisfied with their training at the MOH hospital. The item with least satisfaction was related to the hospital staff being friendly and approachable $(40.2 \%)$, while the item with highest satisfaction was related to adequacy and accessibility of learning resources at hospital (64.1\%). Students enjoyed their training significantly more at university hospital $(p=0.008)$; the staff were significantly less friendly at the MOH hospital ( $p=0.018)$; internship was significantly more preferred at the university hospital ( $p<0.001)$; and students felt as part of the team during their placement significantly less at the MOH hospital $(p<0.001)$. Other satisfaction items did not differ significantly according to students' training hospital.

\section{Discussion}

In this study, most students of the undergraduate Radiological Sciences Program at King Saudi University were generally satisfied with their clinical training, with most of their satisfaction mean scores being above 3 . The least students satisfaction was related to "my performance was observed throughout the placement and there was daily evaluation" and "the hospital staff being friendly and approachable", which indicates that the per- formance of students was not observed properly by hospital staff and there was no proper and daily evaluation.

These students' concerns were reported in the literature as a one of the major dissatisfaction factors. In Australia, Bridge and Carmichael [4] reported that most radiology students were satisfied with their program, but their main concerns were toward hospital staff support more than physical resources; particularly access to a named mentor, a clinical educator and weekly formative feedback. Moreover, Cunningham et al., [5] stressed that clinical educators at hospitals should use assessment strategies for medical radiation sciences students that objectively measure their progress, and should be positive role models for their students.

Findings of the present study showed that the highest mean satisfaction score among the different parameters of clinical posting was "it is important to go to different hospitals for training to have different clinical experiences". This study also showed that training item which met students' highest satisfaction was related to adequacy and accessibility of learning resources at hospital. These findings reflect students' demand to learn, and to take challenging tasks and also their readiness to go for different hospitals during their train- 
ing program. It also indicates that students are well aware about how much clinical posting and training program are important for their success.

This finding is in accordance with that reported by Wareing et al., [6] who noted that students of health care programs usually enjoy new challenges and learning new skills which improve their abilities and chances.

Results of the present study showed that some radiology students satisfactorily met their placement objectives, enjoyed their time and worked as a team with very willing and available staff that assisted them in learning. However, most of these students were dissatisfied with their training at the $\mathrm{MOH}$ hospital.

These findings reveal the need to improve hospital training programs of undergraduate radiological sciences students, especially at MOH hospitals. Henzi et al., [7] indicated that not all practice settings are able to provide students with a positive learning environment, such as adequate and accessible learning resources within the hospital which enhanced learning. On the other hand, Steves [3] stated that the dissatisfaction of student technologists on their clinical training is mainly attributed to the lack of supervision and evaluation during their hospital training, in addition to insufficient training time and the lack of on-going feedback from students and collaboration with the faculty.

In conclusion, radiological sciences students are mainly satisfied with their clinical training.
However, they enjoyed their training at the university hospital more than at a $\mathrm{MOH}$ hospital. Feedback should be regularly taken from students to ensure that they have the best placement and training environment. Educational and training institutions, supervisors and clinical trainers must collaborate to develop and implement strategies in order to improve practice.

\section{References}

1- KYEI K.A., ANTWI W.K., BAMFO-QNAICOA K. and OFFEI R.O.: Challenges faced by radiography students during clinical training. Clinical Medicine Research, 4 (1-3): 36-41, 2015.

2- CUNNINGHAM J., WRIGHT C. and BRAID M.: Managing Clinical Education Through Understanding Key Principles. Radioloic Technology, 86: (3) 257-73, 2015.

3- STEVES A.M.: Improving the Clinical Instruction of Student Technologists. J. Nuclear. Med. Technol., 33: 205-9, 2005.

4- BRIDGE P. and CARMICHAEL M.: Factors influencing radiation therapy student clinical placement satisfaction; Journal of Medical Radiation Sciences, 61: 45-50, 2014.

5- CUNNINGHAM J., WRIGHT C. and BAIRD M.: Managing clinical education through understanding key principles. Radiologic Technology, 86 (3): 257-73, 2015.

6- WAREING M., CHADWICK K. and BAGGS H.: Student satisfaction with worked-based learning: Evaluation of a foundation degree health and social care program. International Journal of Practice-based Learning in Health and Social Care, 2 (2): 65-79, 2014.

7- HENZI D., DAVIS E., JASINEVICIUS R. and HENDERICSON W.: North American dental students' perspectives about their clinical education. Journal of Dental Education, 70 (4): 361-77, 2006.

\section{تقييم ملى رضا الطلاب الجامعيين فى مجال الآثعة نحو خبرتهم فى التدريب السريرى}

$$
\text { الآشعة التشخية: إن التطبيقات الإشعاعية تلعب دورا هاما جدا في نظم الرعاية الصحية. حيث تستند معظم التشخيصات في الوقت الصاضر على }
$$

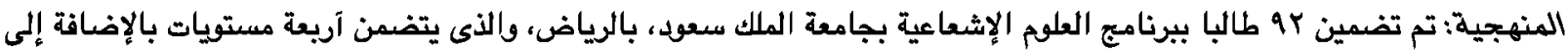

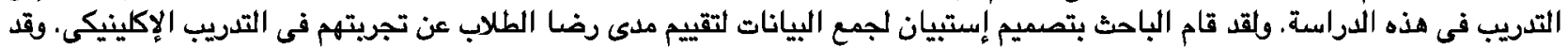

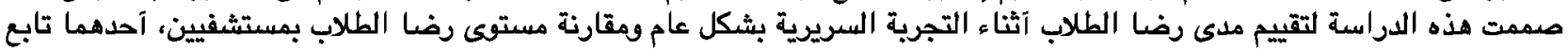
اللجامعة والآخر تابع لوذارة الصرية

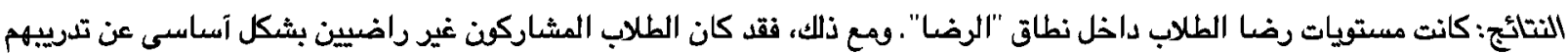

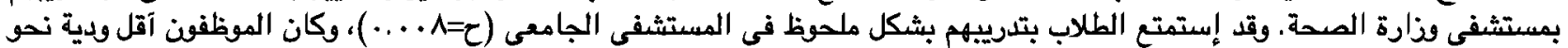

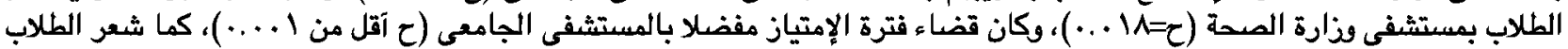

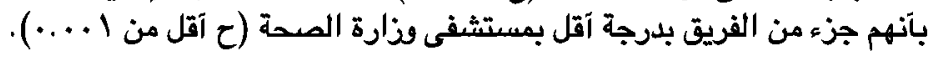

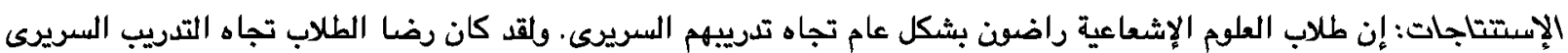

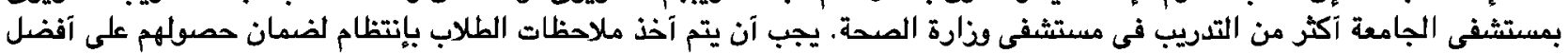

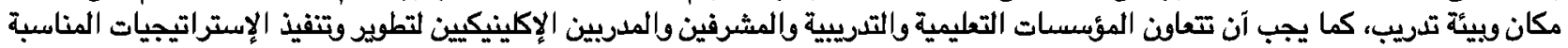

